\title{
Erratum to: Haemopoiesis in the head kidney of tilapia, Oreochromis niloticus (Teleostei: Cichlidae): a morphological (optical and ultrastructural) study
}

El-Saydah H. Abdel-Aziz • Suzan B. S. Abdu •

T. El-Sayed Ali $\cdot$ Huda F. Fouad

Published online: 29 March 2012

(C) Springer Science+Business Media B.V. 2012

Erratum to: Fish Physiol Biochem (2010)

36:323-336

DOI 10.1007/s10695-008-9297-z

Unfortunately, the corresponding author's name has been misspelled in the original publication of the article. The correct name is T. El-Sayed Ali.

The online version of the original article can be found under doi:10.1007/s10695-008-9297-z.

E.-S. H. Abdel-Aziz · T. El-Sayed Ali ( $ه)$

Oceanography Department, Faculty of Science,

Alexandria University, Alexandria, Egypt

e-mail: tameraly@yahoo.com

S. B. S. Abdu - H. F. Fouad

Zoology Department, Girls College of Education, Jeddah,

Saudi Arabia 